\title{
Economic Growth And FDI In China
}

\author{
Francis Cai, (E-mail: caif@ wpunj.edu), William Paterson University \\ Huifang Cheng, Zhejiang University of Technology, China \\ LianZan Xu, (E-mail: xul@wpunj.edu), William Paterson University \\ C.K. Leung, (E-mail: leungc@wpunj.edu), William Paterson University
}

\begin{abstract}
This paper studies the importance of foreign direct investment (FDI) in economic development in China. By analyzing the data from China and comparing China with other developed and developing countries, the paper finds that FDI becomes a force in economic growth, especially in the later stage of industrialization; Specifically, the paper finds that a country's foreign trade is the engine in the initial stage of the economic development, while FDI is the main force in the post-industrialization stage.
\end{abstract}

\section{Introduction}

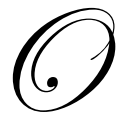

ver the past 20 years, with the globalization of the production and consumption of goods and services, worldwide foreign direct investment (FDI) has experienced a tremendous growth. FDI inflows have grown at an average annual rate of about 25 per cent over the last decade. In practice, it is widely implicitly assumed that FDI will not only lead to an infusion of innovative technologies, management strategies, and workforce practices, it will also help create new jobs, prompt economic growth in recipient countries.

However in academia, as Mello (1999) points out, the search for the keys to economic growth has been arduous in the economic literature. There have been conflicting research results as to whether FDI is the engine of economic growth. Mello (1999) finds that FDI is expected to boost long-run growth in the recipient economy via technological transfers and knowledge spillovers. But the extent to which FDI is growth-enhancing depends on the degree of complementarity and substitution between FDI and domestic investment. Carkovic and Levine (2002) find that FDI does not exert a robust, independent influence on growth at all. Loungani and Razin (2001) suggest that FDI has a beneficial impact on developing host countries with some potential risks. Borensztein, Gregorio, and Lee (1998) find that FDI contributes relatively more to growth than domestic investment. Gardiner (2002) finds that the impact of FDI is dependent on what form it takes and gives a range of positive and negative aspects of FDI as a source of development. Mansfield and Romeo (1980) find that FDI does not accelerate growth. Alfaro, Chanda, Chanda, and Sayek (2002) shows that FDI plays an ambiguous role in contributing to economic growth. Calvo and Sanchez-Robles (2002) suggest that Foreign Direct Investment is positively correlated with economic growth in the host countries of the sample considered.

In this paper we draw on recent progress in the theory of FDI to analyze empirically the important determinants of economic growth in China. By using the data from China and other countries and production functions that depend on domestic capital, foreign direct investment, labor force, export, we will study how FDI plays a role in economic growth in general, and in China in particular, relative to the contribution of foreign trade to economic growth. The country-specific time series data and cross-country panel data will be analyzed to ascertain the impact of FDI on economic growth.

The results of this paper suggest that FDI is an important component of open macroeconomic development and an important variable of open economy. The paper finds that 1) FDI becomes a force in economic growth, especially in the later stage of industrialization; and 2) FDI is a balancing variable in an open macro economic equilibrium. Specifically, the paper finds that a country's foreign trade is the engine in the initial stage of the economic development, while FDI is the main engine in the post-industrialization stage. 
The remainder of this paper is organized as follows. Section II reviews the theory of FDI and growth; Section III discusses the correlation between FDI and economic growth; Section IV provides conclusions.

\section{Literature Survey on Foreign Direct Investment}

The foreign direct investment activities can be traced a century ago. Godley and Fletcher (2000) find that FDI activities in British retailing sector dates back to 1850. However, Economists began to study the theories of foreign direct investment in the 1960's. Foreign direct investment used to be thought of by economists as an international capital movement. In the 1960's the prevailing explanation of international capital movements relied on exclusively upon a neoclassical financial theory of portfolio flows. In a frictionless world of perfect competition, with no transaction costs, capital moves in response to changes in interest rate differentials (See Carl Iversen (1936)). According to this arbitrage theory, capital is assumed to be transacted between independent buyers and sellers, that is, there is no role for a Multinational Corporation (MNC). The work did not even ask the question of "why is there a need for FDI?" despite the evidence of cross-country investments and the existence of large MNC's with inter-industry trade.

Hymer (1960) in his seminal dissertation moves us towards an analysis of MNC's based upon industrial organization theory. The pioneering conceptual insight of Hymer was to break out of the arid model of international trade and investment theory and focus attention upon the MNC's. The unique feature of FDI is a mechanism by which MNC's maintain control over productive activities outside its national boundaries. That is, FDI means international production. Hymer (1960) explains that the MNC is a creature of market imperfections. The MNC has the ability to use its international operations to separate markets and remove competition, or to exploit monopolistic advantage. Hymer (1960) states that control of a foreign subsidiary "is desired in order to remove competition from the foreign enterprise and enterprise in other countries."

Following the publication of Hymer's book, a number of authors had tried to expand the FDI analysis in several directions. Charles P. Kindleberger further moved the discussion of foreign direct investment from international capital movement to international production. Kindleberger argued that direct investment is an international capital movement, but it is more than that. International capital movements take place in a variety of forms -through the issue of new securities, largely bonds; through purchases and sales of outstanding securities, both stocks and bonds, on security exchanges; through direct investment. Kindleberger (1969) argues that Direct investment is different from other kinds of international capital movements in that it is accompanied by varying degree of control, plus technology and management. Kindleberger (1969) focuses FDI' analysis on growth of the firm and monopolistic competition and suggests that direct investment is a function of the growth of the firm. "In growing firms may well go abroad, in going abroad, firms grow abroad." The paper observes that "average half the earnings on foreign investment were reinvestment abroad by the US companies. From this a decision rule was deduced that firms bring home half their winnings and plow back the other half. On this showing the clue to direct investment lay in capital formation and growth of firm."

Balasubramanyam (1996) analyzes the relationship between trade strategy, FDI and growth in developing countries in the context of new growth theory. He argues that externalities, human capital and learning by doing form the main springs of endogenous growth theory. Many of the growth promoting factors identified by new growth theory can be initiated and nurtured to promote growth through FDI, since FDI has long been recognized as a major source of technology and know-how to developing countries. The knowledge created in developed countries with their relatively high endowments of human capital can be transferred to developing countries through FDI. New growth theory, therefore, provides powerful support for the hypothesis that FDI could be a potent factor in promoting growth. Borensztein, Gregorio, and Lee (1998) tests the effect of FDI on economic growth in a crosscountry regression framework and examines the role of FDI in the process of technology diffusion (transmission of ideas and new technology). Results suggest that FDI is an important vehicle of technological transmission and that FDI contributes relatively more to growth than domestic investment. However, FDI contributes to economic growth only when a sufficient absorptive capability of the advanced technologies is available in the host economy. 
These debates have provided rich insights into the relationship between FDI and economic growth. This paper continues this debate by examining FDI and economic growth in developed and developing countries. Despite the fact that the vast majority of foreign direct investment in the world has been in developed countries, there is little discussion on how foreign direct investment affects economic growth of developed countries. In this paper we will study the impact of FDI on economic growth in both developed economy and developing economy.

\section{Model of FDI and Economic Growth}

We use a capital-domestic capital-foreign direct investment-labor-international trade (K,F,L,X) model of economic production function and growth. Capital K, Foreign Direct investment, F, Labor, L and international trade $\mathrm{X}$ are the producing factors of production that generate the industrial output $\mathrm{Q}$. First, the effects of FDI and foreign trade in different economic development stage are different. Second, the strengths and mechanism of FDI in the different economic development process are different.

The model we use to test our hypothesis tries to analyze the relationship between FDI, exports, and economic growth in 14 countries (including 7 developed countries and 7 developing countries) in the context of new growth theory. FDI is introduced in the production function as an input in addition to domestic capital. FDI has been recognized as a major source of technological progress and economic growth. Borensetein (1998) shows that FDI is expected to be a "crowding-in" domestic investment effect, that is, a one-dollar increase in the net inflow of FDI is associated with an increase in total investment in the recipient economy of more than one dollar. Indeed, it is the ability of FDI to transfer not only production know-how, but also managerial skills that distinguish it from all other forms of investment, including portfolio investment.

We also introduce exports as additional factor input into the production function in order to analyze different impacts between FDI and exports in the different countries and different economic development stage. The idea that international trade is the engine of growth is very old, going back at least to Adam Smith. A number of empirical studies have been conducted on the export-led growth hypothesis. Michaely (1977) uses simple rank correlation on a 41-country sample for 1950-70 to analyze whether the rate of growth of exports has been associated with GDP, and their relation with output growth. His results show that the Spearman rank coefficient was significantly positive $(0.308)$ for the sample as a whole. It was large $(0.523)$, however, for a sub sample of 23 middle-income countries. Balassa (1978) also uses the rank correlation methodology to investigate this issue. Using pooled data on eleven countries for 1960-73, his results reveal again positive correlation coefficient between different measures of the rate of growth of exports and output growth. Feder (1983) sets up a simple model with exports sector and a non-exports sector based on neoclassical production function and the results show that marginal factor productivity in the export sector is higher than in the non-export sector. Salvatore and Hatcher (1991) provide three reasons for the explicit introduction of exports into the production function. First, they argue that export orientation is likely to lead higher factor productivity because of the exploitation of economies of scale, better utilization of capacity and lower capital- output ratios. Secondly, they argue that exports are likely to alleviate serious foreign exchange constraints and can thereby provide greater access to international markets. Thirdly, exports like FDI are likely to result in a higher rate of technological innovation and dynamic learning from abroad.

As discussed above, our production function is written as follows:

$\mathrm{Y}=\mathrm{g}(\mathrm{K}, \mathrm{F}, \mathrm{L}, \mathrm{X})$

Where, $\mathrm{Y}$ denotes gross domestic product (GDP), $\mathrm{K}$ is domestic capital (gross fixed capital formation), $\mathrm{F}$ is stock of foreign direct investment, $\mathrm{L}$ is labor force, and $\mathrm{X}$ is export.

For the simplicity, we assume the production function $g$ in (1) is a log linear function. We have the following expression describing the determinants of the growth rate of GDP:

$\mathrm{Y}=\alpha+\beta^{*} \mathrm{~K}+\delta^{*} \mathrm{~F}+\phi^{*} \mathrm{X}+\gamma^{*} \mathrm{~L}+\varepsilon$ 


\subsection{Data Description and Empirical Results}

The data used in this paper are from International Financial Statistics 2001, 1980, 1965, Balance of Payment Statistics Yearbook 1996, and the World Bank Indicators CD-ROM 2001 and IMF CD-ROM 2001. The sample used for analysis contains 15 countries. These countries can be divided into two groups: one is developing economy and the other is developed economy. The sample covers years from 1970 to $2000{ }^{1}$

Before we proceed to our production model analysis, we would like to use Figure I and Figure II to show a comparison of international trade between the developed countries and developing countries over the sample period. Figure I illustrates the Foreign Trade Dependence Degree (FTDD thereafter) defined as the ratio of total trade (exports plus imports) to GDP for five developed countries (United States, United Kingdom, Germany, Japan, and France). It measures the degree of a nation's economic dependence on its foreign trade.

In Figure 1 we plot FTD in these five developed countries over the sample period. Foreign trade dependence degree moved up during the period of 1960's and 1970's in the developed countries such as United States, Japan, United Kingdom, Germany and France, which demonstrates a strong pull force to the economic growth by the foreign trade. Since the mid 1980's foreign trade dependence degree has showed a stable and sluggish increase tendency, and in Japan and Germany this figure has even decreased.

\section{Figure 1: Foreign Trade Dependence Degree Foreign Trade Dependence is defined as the ratio of total trade to GDP}

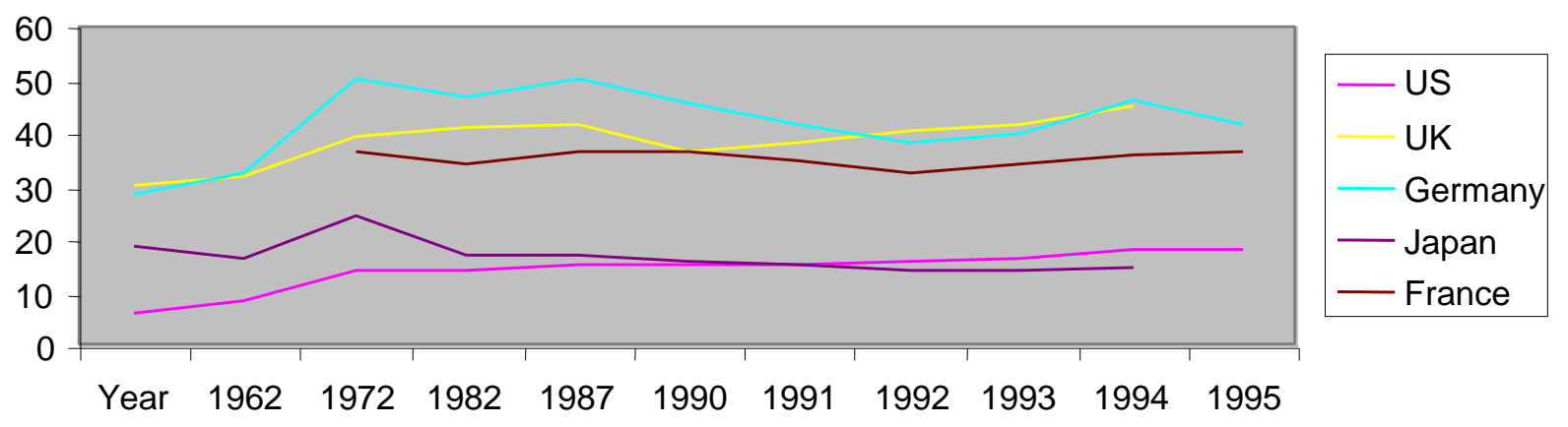

Data source: IMF: International Financial Statistics 1999, Balance of Payment

Figure 2 and Figure 3 chart the trends of Foreign Capital Dependence Degree (FCDD) and Foreign Direct Investment Dependence Degree (FDID thereafter) for the five developed countries. The foreign capital dependence degree is the ratio of its monetary and capital's inflows plus outflows (which include foreign direct investment; stocks, bonds and securities investment; trade credit, loans, deposits, and other investments on long or short term) to GDP ((total capital flows)/GDP). FDID is defined as the ratio of a nation's foreign direct investment inflows and outflows to GDP (TFDI)/GDP), which shows the inter-relation between the international investment and a country's economic growth. These ratios are used to reflect a nation's production internationalization degree and how much a country relies on international capital in developing its economy.

1 Some countries have a short sample period due to lack of data. 
Figure 2: Foreign Investment Dependence Foreign Capital Dependence Degree is defined as the ratio of total capital Inflows and Outflows to GDP

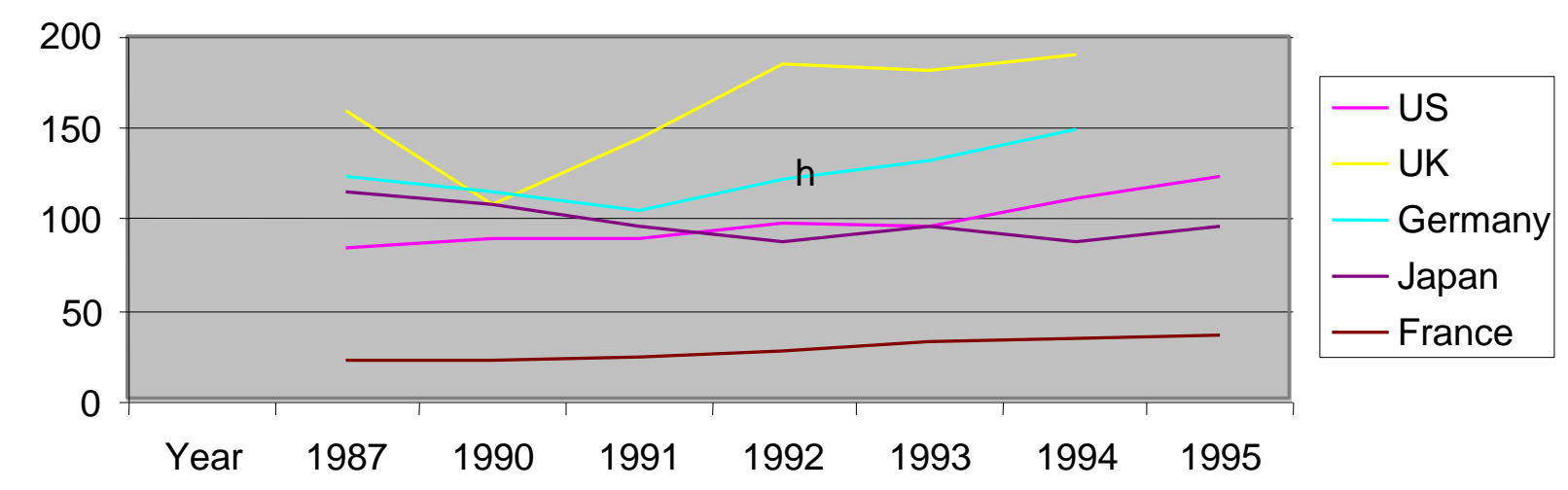

Data source: IMF: International Financial Statistics 1999, Balance of Payment

Figure 3: Foreign Direct Investment Dependence Degree Foreign Trade Dependence Degree is defined as the ratio of total FDI to GDP

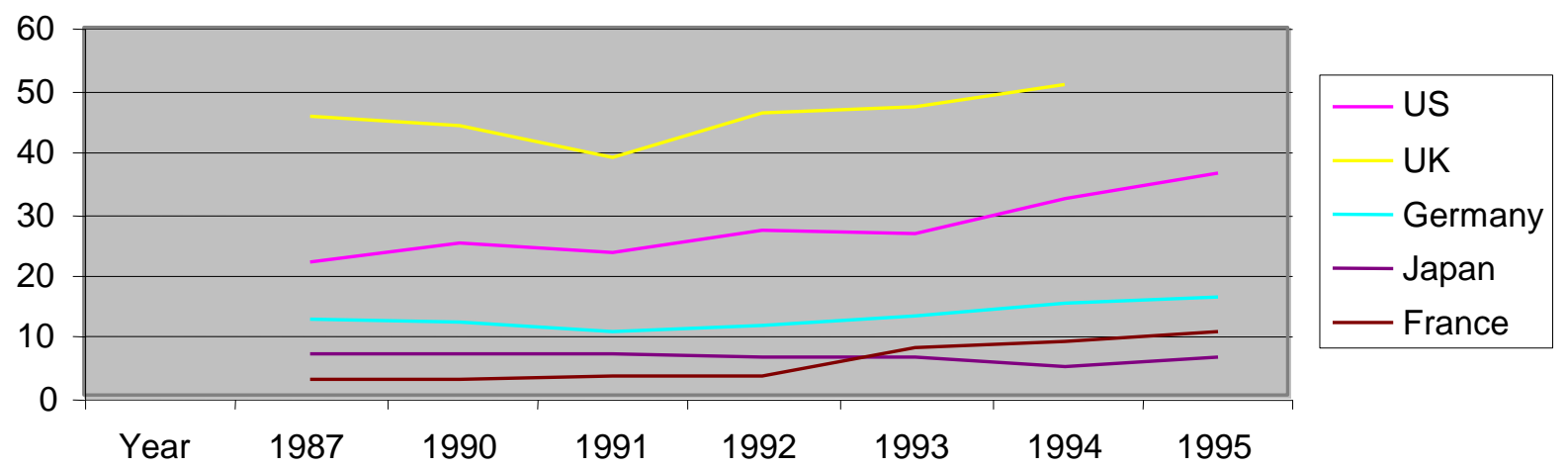

Data source: IMF: International Financial Statistics 1999, Balance of Payment

After entering into the 1980s, especially in the 1990s, with foreign trade dependence degree showing sluggish trends, the foreign investment dependence and foreign direct investment dependence came into a rapid growth process in these countries. In a 5-year period from 1991 to 1995 , there had been an $80.36 \%$ and $4.95 \%$ increase in United Kingdom, 39.7\% and 14.4\% in United States, $24.94 \%$ and $4.95 \%$ in Germany (see Table 2). Only Japan had experienced a decrease in both ratios over the same period. These figures show that the foreign investment dependence degree is much greater than the foreign trade dependence degree, indicating that in these countries the internationalization degree of financial assets is much greater than that of the merchandise.

Table 1 shows the regression analysis of growth rate of real GDP on domestic capital, foreign direct investment, labor force, and exports by 14-country data. 12 out of 14 countries had positive coefficients of foreign 
direct investments, indicating that the overwhelming majority of countries exhibit the pulling force of FDI in their economic growth.

From Table 1, we observe that the coefficient of FDI is positive and t-statistics is significant at $1 \%$ level for China. This result shows that FDI possibly improves the productivity of investment in China. This finding is consistent with our previous discussion on FDI in the developed countries. Ever since the reform and opening in 1978. Chain foreign trade dependence degree increased rapidly from $9.79 \%$ in 1978 to $40.3 \%$ in 1995 . This indicates the foreign trade's pulling function in the nation's economic growth in this period. The experience of the developed countries shows that, when the foreign trade dependence degree grows to a certain level, it will enter into a stable

\section{Table 1 Regression Analysis of Determinations of Growth Rate of Real GDP (1970-1999) \\ $\mathrm{y}=\alpha+\beta \mathrm{k}+\delta \mathrm{f}+\gamma \mathrm{l}+\phi \mathrm{x}$}

$\mathrm{Y}$ denotes gross domestic product (GDP), $\mathrm{K}$ is domestic capital, $\mathrm{F}$ is foreign direct investment, $\mathrm{L}$ is labor force, $\mathrm{X}$ is exports.

\begin{tabular}{|l|c|c|c|c|c|c|}
\hline \multicolumn{1}{|c|}{ Country } & $\boldsymbol{\alpha}$ & $\boldsymbol{\beta}$ & $\boldsymbol{\delta}$ & $\boldsymbol{\gamma}$ & $\boldsymbol{\phi}$ & R-squared \\
\hline Australia & 20.28932 & 0.256748 & 1.254576 & 0.265336 & -0.047284 & 0.477712 \\
t-Statistic & 0.714607 & 0.924336 & 1.555205 & 0.34064 & -1.014629 & \\
\hline Brazil & 0.240797 & 0.604671 & 0.174289 & 0.255572 & -0.002134 & 0.225448 \\
t-Statistic & 0.016395 & 1.481575 & 0.1489 & 0.599447 & -0.847393 & \\
\hline Canada & -9.669696 & 0.427427 & -0.783818 & 0.235109 & -0.000617 & 0.238985 \\
t-Statistic & -0.76007 & 1.317503 & -1.607508 & 1.55049 & -0.09617 & \\
\hline China & -22.41192 & 1.296082 & 4.49863 & -0.566331 & -0.000135 & 0.870238 \\
t-Statistic & -2.6741717 & 8.753355 & $3.217632 * *$ & -2.910839 & -0.881693 & \\
\hline France & -18.38919 & 0.439741 & 0.020897 & 0.060926 & 0.003907 & 0.26279 \\
t-Statistic & -0.964015 & 2.020546 & 0.116794 & 0.250614 & 0.557817 & \\
\hline India & 4.991848 & 0.165237 & 1.694427 & 2.610582 & -0.000758 & 0.398563 \\
t-Statistic & 0.457997 & 0.343633 & 0.088804 & 1.338955 & -1.263888 & \\
\hline Indonesia & -15.48544 & 1.457836 & 7.814265 & 0.119383 & -0.003507 & 0.459176 \\
t-Statistic & -0.830552 & 2.919421 & 0.978785 & 0.593986 & -1.708677 & \\
\hline Italy & 21.936 & -0.337105 & -2.591324 & -0.100811 & -0.003119 & 0.125967 \\
t-Statistic & 0.459214 & -0.629096 & -1.203114 & -0.487004 & -0.201491 & \\
\hline Japan & 10.0896 & 0.167405 & 0.805338 & -0.175231 & -0.001578 & 0.254509 \\
t-Statistic & 0.503718 & 0.572934 & 0.942142 & -0.684413 & -0.896492 & \\
\hline Malaysia & 2.236046 & 0.220775 & 1.36097 & -0.005512 & -0.007555 & 0.442827 \\
t-Statistic & 0.575119 & 1.155174 & 1.376661 & -0.04642 & -0.421746 & \\
\hline Mexico & -15.23204 & 1.011426 & 2.991305 & -0.216487 & -0.00095 & 0.508198 \\
t-Statistic & -1.790312 & 2.850761 & 0.999005 & -1.170506 & -0.732848 & \\
\hline Thailand & 1.624437 & 0.612056 & 0.678899 & -0.098565 & -0.003993 & 0.729093 \\
t-Statistic & 0.3321194 & 5.147151 & 0.225231 & -0.457737 & -1.0205 & \\
\hline UK & 0.066632 & 0.768341 & 0.122107 & 0.726764 & -0.01067 & 0.826077 \\
t-Statistic & 0.002052 & 3.45171 & 0.972867 & 3.854319 & -0.946172 & \\
\hline USA & -24.18011 & 0.874554 & -0.305523 & -0.546865 & 0.001337 & 0.417592 \\
t-Statistic & -2.358699 & 3.13743 & -0.339995 & -1.253237 & 1.978124 & \\
\hline Total Sample & -0.53 & 0.173 & 0.005 & 0.001 & & 0.064 \\
t-Statistic & -1.24 & -9.619 & -0.201 & -1.636 & & \\
\hline
\end{tabular}

**-- significant at $1 \%$ level

Data Source: World Bank Indicators CD-ROM 2001 and IMF CD-ROM 2001 
phase, while the foreign capital dependence degree and foreign direct investment dependence degree will show their distinct growth rates and play more important roles in economic internationalization and economic growth. The similar pattern also occurred in China. Since 1990, the foreign investment dependence degree has increased dramatically. Although not going down like most of the developed countries, foreign trade dependence in China starts to show less dramatic positive role in the economic growth lately. It is likely that in the future the dependence degree of foreign capital and that of foreign direct investment will continue to grow, and the foreign direct investment will serve as the new engine and source of the nation's economic growth

To further understand the importance of FDI in the later stage of economic growth, we pool 130 country data and divide them into four groups of panel data. We run the regression analysis of growth rate of real GDP on domestic capital, foreign direct investment, labor force and the regression results are listed in Table 2.

Table 2 Regression Analyses of Production Functions By High Income, Middle Income, and Low Income Country Data (1995)

$$
y=\alpha+\beta k+\delta f+\gamma l
$$

$\mathrm{Y}$ denotes gross domestic product (GDP), $\mathrm{K}$ is domestic capital, $\mathrm{F}$ is foreign direct investment, and $\mathrm{L}$ is labor force. The numbers in parentheses are t-statistics.

\begin{tabular}{|l|c|c|c|c|c|}
\hline \multicolumn{1}{|c|}{ Country Group } & $\mathbf{A}$ & $\boldsymbol{\beta}$ & $\boldsymbol{\delta}$ & $\gamma$ & R-squared \\
\hline Total Sample & -0.53 & 0.173 & 0.005 & 0.001 & 0.064 \\
$(\mathrm{n}=40)$ & $(-1.24)$ & $(9.619)$ & $(0.201)$ & $(-1.636)$ & \\
\hline High Income & -0.963 & 0.161 & 0.107 & 0.001 & 0.083 \\
$(\mathrm{n}=22)$ & $(-1.31)$ & $(5.338)$ & $(2.959)$ & $(0.000)$ & \\
\hline Low Income & -2.403 & 0.304 & 0.009 & 0.007 & 0.213 \\
$(\mathrm{n}=18)$ & $(-3.43)$ & $(9.572)$ & $(0.119)$ & $(1.639)$ & \\
\hline
\end{tabular}

Data Source: $\quad$ World Bank Indicators CD-ROM 2001 and IMF CD-ROM 2001

Table 2 shows that the coefficient estimates of the variable FDI are not significant for the whole sample panel or for the low income country data. However the coefficient estimate of the variable FDI is positive and significant for the high income country data. This suggests that FDI has positive correlation with economic growth for the developed countries. This finding confirms the discussion above that foreign direct investment dependence degree will show their distinct growth rates and play more important roles in economic internationalization and economic growth in the later stage of the economic development.

\section{Conclusions}

This paper studies FDI in the context of an open macroeconomic equilibrium. By using the data from fourteen countries (seven developed countries and seven developing countries) and production functions that depend on domestic capital, foreign direct investment, labor force, export, we study how FDI plays a role in economic growth in the developed economy and developing economy relative to the contribution of foreign trade to economic growth. The country-specific time series data and cross-country panel data are analyzed to ascertain the impact of FDI on economic growth.

The results of this paper show that FDI is an important component of open macroeconomic development and an important variable of open economy. The paper finds that 1) FDI becomes a force in economic growth, especially in the later stage of industrialization; and 2) FDI is a balancing variable in an open macro economic equilibrium. Specifically, the paper finds that a country's foreign trade is the engine in the initial stage of the economic development, while FDI is the main engine in the post-industrialization stage. 


\section{References}

1. Alfaro, Laura, Areendam Chanda, Areendam Chanda, and Selin Sayek (2001), "FDI and Economic Growth: The Role of Local Financial Markets", April 2002, North Carolina State University Working Paper.

2. Balasubramanyam, V.N., M. Salisu and David Sapsford (1996). "Foreign direct investment and growth in EP and IS countries" The Economic Journal, 106, pp.92-105.

3. Borensztein, Eduardo, Jose De Gregorio, and Jong-Wha Lee (1998), "How Does Foreign Direct Investment Affect Economic Growth?” Journal of International Economics, Vol. 45, pp 115-35.

4. Calvo, Marta Bengoa And Blanca Sanchez-Robles, "Does Foreign Direct Investment Foster Economic Growth? Some Theoretical And Empirical Arguments". Universidad de Cantabria, Working Paper Series.

5. Carkovic, Maria and Ross Levine, (2002), "Does Foreign Direct Investment Accelerate Economic Growth?" World Bank Paper.

6. Gardiner, Rosalie, "Foreign Direct Investment: A Lead Driver for Sustainable Development", 2002, Economic Briefing Series No 1, Earth Summit 2002.

7. Godley, A. and Fletcher, S. (2000) "Foreign direct investment in British Retailing, 1850-1962" Business History, 42 (2), April, pp.43-62.

8. Graham, E., Krugman, P., 1991. "Foreign Direct Investment in the United States", Institute for International Economics, Washington DC.

9. Hymer S. (1960). "International Operations of National Firms: A Study of Direct Foreign Investment", Doctoral Dissertation, Massachusetts Institute of Technology.

10. IMF: International Financial Statistics CD-ROM.

11. IMF: Balance of Payment Statistics Year Book.

12. Kindleberger C P. "American Business Abroad: Six Lectures on Direct Investment", New Haven, Yale University Press.

13. Loungani, Prakash and Assaf Razin, (2001) "How Beneficial Is Foreign Direct Investment for Developing Countries?" Finance and Development, June 2001, Volume 38, \#2.

14. Luiz R. de Mello, Jr. (1999). "Foreign Direct Investment-led Growth: Evidence from time Series and Panel Data", Oxford Economic Papers 51, pp. 133-151.

15. Mansfield, E. and A. Romeo, 1980, "Technology transfers to overseas subsidiaries by US-based firms", Quarterly Journal of Economics, 95, No.4, pp. 942-963. 